\title{
"Kvinna i brist på bättre ord": Självkategorisering som utgångspunkt för en inkluderande språkvetenskap
}

\author{
Alexis Rancken
}

\section{Introduktion}

Då jag för några år sedan inledde min forskning om svenska språket och queera identiteter skickade jag ut en enkät där informanterna fick möjlighet att med egna ord beskriva sin könsidentitet och sexualitet. Tanken var att svaren främst skulle fungera som bakgrundsvariabler, men jag insåg snabbt att de i själva verket utgjorde den kanske mest fascinerande delen av mitt material. Möjligheten till självkategorisering visade på att det finns aspekter av kön och sexualitet som sällan beaktas i språkvetenskaplig forskning, och framför allt kännetecknades svaren av en enorm mångfald och i många fall avståndstagande från traditionella kategorier, eller till och med själva kategoriseringsprocessen.

Den här artikeln, som ingår i min doktorsavhandling om svenska språket och icke-normenliga identiteter, handlar om varför vi måste betrakta kön och sexualitet som mer än sociolingvistiska bakgrundsfaktorer - självkategoriseringarna har vetenskapligt egenvärde och de utmanar den syn på sociala kategorier som ännu är dominerande inom språkvetenskapen. De har även politisk relevans: ett inkluderande och jämställt språk hör till målsättningarna för den queerfeministiska språkaktivism som bland annat införandet av det könsneutrala pronomenet hen gett luft under vingarna, men liknande reformer kan inte planeras eller genomföras ifall vi inte känner till vilka det är som ska inkluderas och synliggöras.

Mitt syfte är här att, efter en översikt över tidigare språk- och genusvetenskaplig forskning kring identitetskategorier, presentera 211 självidentifierat queera personers beskrivningar av sin egen identitet för att sedan på basis av dessa diskutera hur icke-normenliga identiteter bättre kunde inkluderas i forskningen kring språk, kön och sexualitet. Genom att lägga särskild fokus på beskrivningarnas förhållande till de normativa strukturer som existerar gällande kön och sexualitet hoppas jag kunna bidra med kunskap om såväl queera identiteter som det normsystem de utmanar.

\section{Queerteoretiska modeller för organisering av kön och sexualitet}

I det här avsnittet kommer jag kort att ta upp de queerlingvistiska modeller och den terminologi artikeln bygger på för att i följande avsnitt diskutera språkvetenskapens förhållningssätt till identitetskategorier - och därtill relaterad problematik - samt möjliga lösningar. Jag kommer att avända Lann Hornscheidts (2015 s. 31f) genderism-modell och då särskilt begreppen cisgendering och binary gendering som ett sätt att förstå normsystemen kring kön medan jag i samband med diskussionen om normerna kring sexualitet främst utgår från Cameron och Kulick (2003) samt Ambjörnsson (2006). 
Då kön ställs upp som en bakgrundsvariabel i språkvetenskaplig forskning är det nästan undantagslöst binära och cisnormativa könssystemet som reproduceras, det vill säga tanken om kön som biologiskt förankrat i två kategorier och dessutom oföränderligt. Med cisgendering avser Hornscheidt (2015:37) "the realization form of genderism that constructs women and men as coherent, natural genderings which are given at birth and which remain constant over time throughout a person's life". Binary gendering, i sin tur, innebär att kvinnor och män är de enda existerande könskategorierna (ibid.:33). Hornscheidt (2015:33) skriver att det manliga och kvinnliga visserligen kan vara förhandlingsbart inom det binära systemet och även transpersoner kan eventuellt få plats, men själva tvåkönsnormen ses inte som en språklig/social konstruktion utan den är "naturlig" och "självklar". I genderism-modellen ingår även androgendering (mannen som norm), reprogendering (kvinnans betydelse reduceras till fortplantning) och heterogendering (normaliseringen av heterosexualitet), och tillsammans upprätthåller dessa könande praktiker en maktordning där vissa identiteter marginaliseras (ibid.:32ff).

Indelningen i (biologiskt/juridiskt) kön och genus, på engelska sex och gender, innebär att åtskillnad görs mellan kroppsliga och sociala/psykologiska aspekter på kön. Mer queerteoretiskt orienterade språkvetare, som tenderar att utgå från Butlers tanke om performativitet, uppfattar detta som problematiskt eftersom även det som anses vara könets kroppsliga aspekter konstrueras och reproduceras diskursivt, alltså genom terminologi och andra språkliga medel (Zimman 2014:14). Något egentligt "biologiskt kön" finns alltså inte a priori, utan bara en uppsättning egenskaper hos kroppar (till exempel genitaliernas utseende, bröstens storlek, behåring) som klumpas ihop till två kategorier och som, ofta kombinerat med psykologiska och sociala egenskaper, sedan anses utgöra könet. Barrett beskriver förhållandet mellan sex och gender så att det förra utgår från det senare, snarare än tvärtom (2002:32). Kroppsliga aspekter kan ändå vara centrala till exempel för transpersoner som upplever könsdysfori och vars psykiska hälsa kan kräva en könskorrigeringsprocess där hormonbehandling och kirurgi ingår. Att helt bortse från kroppsliga aspekter då könsidentiteter teoretiseras skulle vara ett misstag, men detta innebär givetvis inte att dessa aspekter ska betraktas som inherent könade, utan snarare är de potentiellt betydelsefulla vid konstruktionen av en könsidentitet och vid självkategorisering. Zimman (2014:18ff) har till exempel skrivit om hur transmän konstruerar sina kroppar med hjälp av språkliga verktyg. Detta gäller även för till exempel beteenden och utseendemässiga faktorer - snarare än att se dem som en följd av könstillhörighet borde vi analysera hur de utnyttjas performativt och vilken mening de ges vid konstruktionen av individens könsidentitet.

Vårt sätt att tala om sexualitet, i sin tur, innebär ofta att förekomsten av olika sexuella identiteter är en följd av kategoriseringen i kön. Tvåkönssystemet kunde då tänkas resultera i indelningen i heterosexuella, homosexuella och bisexuella individer. Ambjörnsson (2006:65) ser ändå heteronormen som primär i det här avseendet: uppdelningen i två kön är en följd av normaliseringen av heterosexualiteten så att begreppen man och kvinna kräver en heterosexuell referensram för att kunna existera. Även om kön och sexualitet kan analyseras separat finns en stark diskursiv koppling som sannolikt färgar synen på bägge kategorierna, inte bara inom språkvetenskapen utan även i vardagsspråket. Heteronormen ses i regel som central vid forskning om icke-normativ sexualitet, men Cameron och Kulick (2003:134) påpekar att 
fokus på homosexuella män och lesbiska kvinnor utgår från en västerländsk syn på sexuell identitet och forskningen bör därför inte begränsa sig till dessa.

Liksom i fråga om kön finns det nämligen många olika aspekter som kan betonas vid beskrivningen av sexuell identitet, och även om kön givetvis spelar en central roll i och med heteronormen finns det också andra normer som kan påverka självkategoriseringen. Ett exempel är tvåsamhetsnormen, ett annat normativa uppfattningar kring sexuella handlingar. Därmed kan till exempel samtidiga relationer med flera personer och BDSM-sex uppfattas som icke-normenliga även om parterna är heterosexuella. På samma sätt finns det ett normsystem kring förekomsten av sexuell dragning till andra personer överhuvudtaget, vilket innebär att asexuella och demisexuella kan identifiera sig som queera. Ambjörnsson skriver att kategorisering av människor enligt sexualitet överhuvudtaget är ett rätt nytt fenomen, och en betydelseförskjutning har skett även i fråga om termen heterosexualitet (2006:27). Terminologin kring sexuella identiteter är kanske just delvis därför snårig, och kan överlappa könskategorier till exempel så att butch i regel avser en homosexuell kvinna vars utseende är maskulint. Termer som metrosexuell och den medicinska diagnosen transsexuell syftar däremot endast på kön, något som kan kopplas till den ambiguösa engelska termen sex. Cameron och Kulick (2003:106) har föreslagit desire, i översättning begär, som ett komplement till identitetskategorier vid forskning kring sexualitet, men som Eckert påpekar är det inte existensen av sociala kategorier som är problemet utan vårt sätt att handskas med dem (Eckert 2002:100). Att en forskare kategoriserar beteenden och identiteter kan vara problematiskt, men vi kan inte heller bortse från faktumet att många människor de facto kategoriserar sig själva enligt sexualitet.

Vad innebär det att ha en queer könsidentitet eller sexualitet? Enligt Ambjörnsson bör orden som används i diskussionen om identiteter analyseras i förhållande till andra ord, inte i förhållande till någon form av objektivt förnimbar verklighet (2006:27). Någon stabil innebörd för de olika termerna kan därmed inte fastställas. Vilka identiteter som kan uppfattas som icke-normenliga eller queera är alltså även det förhandlingsbart och kopplat till intersektionella faktorer, omgivning och perspektiv. Personer med en sinsemellan liknande identitet kan alltså positionera sig utanför eller innanför den queera sfären beroende på kontextuella faktorer samt den egna synen på kön och sexualitet. I den här artikeln ställer jag därför inte själv upp några kriterier för queera identiteter, utan jag utgår från självkategorisering och de definitioner av termen queer som mina informanter formulerat.

\section{Kön och sexualitet som lingvistiska kategorier}

Forskningen om språk och kön är i hög grad skillnadsfokuserad, även då syftet är uttalat feministiskt. Att systematiskt leta efter skillnader i något som uppfattas vara mäns och kvinnor språkbruk reproducerar inte bara tvåkönsnormen, utan riskerar även att förstärka de essentialistiska uppfattningar som ligger bakom den i och med att frågan tenderar att vara hur snarare än varför. Man undersöker alltså på vilket sätt (binärt) kön reflekteras i språkbruket utan att beakta språkets inverkan på själva konstruktionen av kön (Bing \& Bergvall 1998:497f). Det cisnormativa kommer i sin tur till uttryck i att kön betraktas som en stabil kategori, jämförbar med till exempel födelseår, vilket innebär att tidigare och samtidiga identiteter riskerar att osynliggöras. 
Wojahn (2015:46) urskiljer tre tydliga trender i den feministiska språkforskning som hittills utförts. För det första ligger fokus ofta på språkliga aktörer som har stort och även mer formellt inflytande på språkplaneringen, som till exempel utbildningsväsendet, lagstiftande organ och vissa enskilda språkvetare. För det andra ligger fokus på den form av diskriminering Hornscheidt betecknar som androkönande, det vill säga normaliseringen av mannen som representant för det mänskliga och därmed bortnämning av kvinnor. Hornscheidt (2015:3233) exemplifierar androkönande med benämningar som "fotboll" och "damfotboll", där den förstnämnda ingalunda är könsneutral utan spelarna kan antas vara män utan att någon precisering krävs. För det tredje är den feministiska språkkritiken enligt Wojahn (2015:48) fortfarande inte särskilt vanligt förekommande i Sverige, jämfört med situationen i till exempel de engelska och tyska språkområdena.

Även inom den feministiska språkvetenskapen har man tenderat att se tvåkönsmodellen som på förhand given och sedan lagt fokus på de former av diskriminering som förekommer inom denna modell, till exempel genom att analysera hur könsrollerna konstrueras och upprätthålls i skolmiljö, i arbetslivet, i den privata sfären och så vidare. Den här typen av undersökningar är utan tvivel värdefulla, men utgångspunkten är problematisk eftersom kategorierna inte nödvändigtvis granskas kritiskt eller ens teoretiseras i någon större utsträckning, vilket kan leda till att personer vars identitet inte är normenlig osynliggörs och att intersektionella perspektiv som kunde ha varit relevanta faller bort. Då språkvetenskapen däremot influeras av queerteoretiska perspektiv måste vi gå längre än så: vi kan inte bara identifiera vissa personer som vi anser vara "queera" i någon bemärkelse för att sedan analysera deras språkbruk och eventuellt hitta mönster, utan vi måste modifiera vår syn på sociala kategorier från den traditionella sociolingvistikens där de accepteras som a priori till en mer konstruktivistisk version, där de är diskursivt skapade sociala konstruktioner som då även kan omförhandlas (Barrett 2002:28).

Om strävan är att queera språkvetenskapen måste vi enligt Barrett revidera flera språksociologiska grundteser (2002:26). Särskilt inom mer kvantitativt inriktad forskning är identitetskategorierna så gott som alltid på förhand givna; de ses som inherenta och därmed oföränderliga och deras antal är av tekniska skäl kraftigt begränsat (Barrett 2002:28ff). Risken är då att forskaren helt enkelt reproducerar rådande normer kring kön och sexualitet snarare än att försöka förstå mekanismerna bakom dem och kanske även utmana dem. Queerperspektivet för oss bortom de essentialistiska idéer som kännetecknar mycket av vårt tänkande kring kön och sexualitet, och riktar istället vår blick mot bredare frågor om hur identiteter konstrueras diskursivt och vilket inflytande till exempel rådande maktförhållanden och normsystem har på konstruktionen av identiteter samt det språkbruk som är förknippat med dessa. Detta gäller inte bara för kategorier ordnade kring kön och sexualitet, utan många queerteoretiska tankegångar kan överföras till diskursen kring social kategorisering över lag.

Jag har förutom den queerlingvistiska referensramen använt mig av prototypteori som ett bredare språkfilosofiskt ramverk för min analys av sociala kategorier. Den aristoteliska synen på kategorier, där någonting (eller någon) antingen tillhör eller inte tillhör en kategori, är inte särskilt anpassad för sociala kategorier som kön. I fråga om föremål som möbler eller klädesplagg fungerar skarpa gränser för kategorierna någorlunda väl, men eftersom kön liksom andra sociala kategorier inte har någon oberoende existens, utan skapas och omförhandlas diskursivt, blir gränserna kategorier emellan nödvändigtvis suddiga. 
Här kunde därför andra sätt att teoretisera kategoriseringsprocessen, som till exempel prototypteorin, tas in. Visser (1996:590) skriver att prototypteorin så som den beskrivs av Rosch bygger på idén om att processen där mening skapas kretsar kring mänsklig interaktion, perception och förståelse, vilket innebär att kategorierna är flytande och ofta överlappande. Fox (2011:155) urskiljer till exempel en mängd egenskaper, eller attribut, som associeras med kategorin kvinna - allt från produktionen av östrogen och progesteron till sådana fritidsintressen och yrkesval som i personens kultur ses som lämpliga för kvinnor - men ingen av dessa egenskaper är i sig nödvändig för kategorisering som kvinna. Den syn på kön och sexualitet jag här för fram placerar självidentifieringen, även den en egenskap som listas av Fox (ibid.), som ett slags kärna i varje kategori som sedan de övriga, icke-nödvändiga attributen förknippade med varje kategori kretsar kring. Detta möjliggör överlappande och flytande identiteteskategorier som överensstämmer bättre med queerteoretiska perspektiv än mer snäva och formella kategoriseringsmodeller.

Jag har valt att analysera självkategorisering av kön och sexualitet i olika avsnitt, men i bägge kommer även den andra kategorin att aktualiseras. Den prototypiska synen på kategorier innebär att kön kan fungera som attribut, alltså en egenskap som har någon form av betydelse, vid kategorisering av sexualitet, och eventuellt även tvärtom så att sexualiteten kan påverka könskategoriseringen.

\section{Material}

Materialet jag här använder består av enkätsvar insamlade för min doktorsavhandling. Utskick av hela enkäten, där även frågor angående pronomen och förnamn ingick, gjordes till olika svenska och finlandssvenska HBTQ-organisationers e-postlistor, forum och Facebookgrupper. Enkäten besvarades av 56 personer i Finland år 2012 och 155 personer i Sverige år 2013.

I föreliggande artikel som är en delstudie för min avhandling kommer jag att analysera sammanlagt 211 personers svar på frågorna vilket kön de för tillfället identifierar sig med (här gav jag i samband med frågan exemplen "man", "androgyn" och "inget alls" för att förtydliga att svarsalternativen inte var begränsade till de juridiska kön som accepteras i Finland och Sverige) och vilken deras sexuella identitet är. Frågorna var öppna. Dessutom kommer jag att ta upp svaren på den icke-obligatoriska frågan om eventuella tidigare könsidentiteter, som besvarades av 68 personer. Den gemensamma nämnaren för informanterna är att de identifierar sig som queera i fråga om kön och/eller sexualitet samt att de använder svenska i sin vardag, men inte nödvändigtvis som enda språk eller modersmål.

\section{Analysmetod}

Analysen baserar sig i första hand på Horncheidts tidigare nämnda genderism-modell, som systematiskt redogör för de sammanflätade normsystemen kring kön och sexualitet. Analysen är upplagd enligt fyra temafrågor, närmare bestämt: 
- Vilken eller vilka aspekter av kön/sexualitet betonas i svaret?

- Ligger fokus på precis självkategorisering eller strävar informanten efter att undvika kategorisering överhuvudtaget?

- I vilket förhållande står svaret till tvåkönsnormen och cisnormen respektive heteronormen?

- Förekommer referens till andra normsystem och hur positionerar sig informanter i så fall i förhållande till dessa?

För varje enskilt svar har jag letat efter formuleringar relaterade till de olika normsystemen. Till exempel pekar förleden trans- på en identitet utanför cisnormen, liksom en uppräkning av flera samtidiga eller växlande identiteter som kan markeras genom användningen av till exempel bindeord som och. Olika typer av negationer är även intressanta, eftersom de markerar hur informanten inte kategoriserar sig. Osäkerhetsmarkörer, som kanske, pekar även de på alternativa positioneringar. Jag har sedan redogjort för de olika grupperna av svar enligt de ovan nämnda temafrågorna.

I fall där en viss term använts av fler än enstaka informanter har jag inkluderat antal belägg, men i övrigt ligger fokus på innehåll snarare än kvantitativa aspekter. Jag har använt mig av föreningen Regnbågsankans (en svenskspråkig HBTIQ-organisation i Finland) och RFSL:s ordlistor vid tolkningen av vissa termer som använts i svaren. Möjligheten att jag feltolkat särskilt mer otydligt formulerade svar kvarstår ändå, eftersom begreppsapparaten kring kön och sexualitet är mångfacetterad och instabil.

\section{Självidentifiering i fråga om kön}

I det här avsnittet kommer jag först att diskutera vissa drag på den textuella nivån hos informanternas beskrivningar av sin könsidentitet, för att ge en helhetsbild av materialet. Därefter granskar jag beskrivningarna ur ett semantiskt perspektiv och ordnar dem enligt förhållande till dels tvåkönsnormen, dels cisnormen. Sist redogör jag för i vilken utsträckning informanterna överhuvudtaget vill identifiera sig med något kön och i vilken mån osäkerhetsmarkörer förekommer i självkategoriseringen.

Trots att informanterna gavs möjlighet att formulera även längre beskrivningar av sin könsidentitet är svaren mycket kortfattade. Drygt två tredjedelar av svaren på frågan om vilket kön informanterna identifierar sig med består av endast ett ord, till exempel "man", "androgyn" eller "kvinna". Något som eventuellt kan ha spelat in var exempelsvaren som bestod av ett eller två ord, och informanterna kan också ha påverkats av tidigare erfarenheter av enkätundersökningar där utrymmet är begränsat - ofta dessutom till två eller högst tre rutor (man, kvinna, annat) varav en ska kryssas i. Med ett enda undantag bestod de övriga svaren av två till elva ord, i regel i listform ("androgyn, kvinna") eller i form av en nominalfras med huvudord och attribut ("Genderqueer man"). Det längsta svaret består av fem meningar och skiljer sig därmed markant från de övriga.

68 av informanterna, det vill säga en tredjedel, kategoriserar sig som kvinnor utan preciseringar eller alternativa formuleringar. På samma sätt kategoriserar sig en knapp femtedel, 37 personer, helt enkelt som män. Dessa informanter har en identitet som inte nödvändigtvis bryter mot tvåkönsnormen, men det här innebär inte nödvändigtvis att de är cispersoner, 
något jag diskuterar senare i detta avsnitt. Många andra informanter använder sig också av orden man eller kvinna i sina svar, men väljer att precisera vad detta innebär eller lägga till alternativa formuleringar. Beskrivningar av den här typen är till exempel "genusneutral man", "oftast kvinna (genderfluid)", "Queer, man", "Skiftande, främst kvinna" och "kvinna, huvudsakligen". Personerna med den här typen av identitet upplever alltså inte termerna man och kvinna som fullständigt adekvata, utan vill till exempel tillägga att deras identitet inte är stabil eller att de i något avseende inte motsvarar normen för män och kvinnor. Eventuellt kan det handla om en motstridighet mellan till exempel juridiskt kön och könsidentitet, det vill säga omgivningens kategorisering versus självkategorisering. I några beskrivningar syns referenser till det binära könssystemet i adjektiv som, till exempel "(...) kvinna med manliga drag”, "manlig androgyn" och "nära androgyn med kvinnlig betoning". Här anspelar dessa ord inte nödvändigtvis på essentialistiska uppfattningar om binärt kön, utan man kan tänka sig att adjektiven har en koppling till kulturella uppfattningar om utseende och beteende.

Beskrivningen "Okvinnlig kvinna” refererar sannolikt just till de traditionella könsrollerna - ordvalet tyder på att omgivningens och informantens egna uppfattningar om kvinnlighet i något avseende är olikartade. Svaret "Kvinna i brist på bättre ord" är även det intressant: vilken typ av ord hade i det här fallet bättre speglat informantens könsidentitet, och i vilket avseende är termen kvinna problematisk? Trots att många av mina informanter är aktiva i de svenska och finländska HBTQ-organisationernas grupper på Facebook eller finns på organisationernas e-postlistor är de inte nödvändigtvis insatta i den terminologi som under de senaste decennierna uppstått kring identiteter utanför normerna. En annan möjlighet är att tillräcklig terminologi inte ännu existerar i svenskan, något som avspeglas $i$ att några informanter använder sig av engelska termer ("male-to-intergender", "Ftm transgender"). Olika typer av osäkerhetsmarkörer, som i svaren "Man, antar jag" och "tveksam" kan antingen tyda på att informanten är osäker på sin identitet eller inte hittar rätt ord för att beskriva den.

De som beskriver sig som män och kvinnor väljer ibland att också inkludera andra aspekter av den egna identiteten. Tre av informanterna låter till exempel sexualiteten ingå i sina svar; en kategoriserar sig som "homosexuell man", den andra som "Bisexuell kvinna" och den tredje som "Bög". Eftersom kön och sexualitet ofta hänger samman diskursivt, till exempel så att termen queer omfattar icke-normenliga identiteter och beteenden inom bägge kategorierna, är det knappast någon överraskning att referens till sexualiteten förekommer även i svaren på frågan om könsidentitet. En annan social kategori som inte betonas lika direkt men där någon form av kategorisering ändå antyds i några fall är ålder. En informant uppger helt enkelt "tant" som sin könsidentitet, medan ordet kille förekommer i flera svar ("Transkille", "Androgyn kille", "kille, genderqueer"). Den kvinnliga motsvarigheten till kille, tjej, förekommer också ("Queer tjej") liksom pojke ('Pojke, inget alls").

I flera av beskrivningarna där orden man och kvinna förekommer positionerar sig informanten utanför cisnormen genom olika typer av preciseringar. Exempel på sådana är "Oftast kvinna (genderfluid)", "Skiftande, främst kvinna", "Transkille" och "man, kvinna, trans*, transperson, intergender, bigender, androgyn, genderfluid" - här ligger fokus på könet som föränderligt över tid och eventuellt även som situationsbundet. Även om en transperson har en identitet som man eller kvinna kan hen känna behov av att inkludera tidigare kategoriseringar och identiteter i sin nuvarande, till exempel just genom förleden trans-. Ett fåtal informanter kategoriserar sig dessutom som både man och kvinna, något som i en icke-queer 
referensram skulle ses som motstridigt: "både man och kvinna", det redan tidigare nämnda "man, kvinna, trans*, transperson, intergender, bigender, androgyn, genderfluid" och "både och" är exempel på sådana identiteter. I ett av svaren, "intersex", ligger fokus på medfödda kroppsliga aspekter som placerar personen i fråga utanför cisnormen.

Termen androgyn, som refererar till närvaron av egenskaper med koppling till såväl det maskulina som det feminina, används av 14 informanter, antingen ensamt eller som komplement/alternativ till andra termer. Intergender är en annan term som är rätt vanligt förekommande, och refererar till en positionering mellan eller eventuellt bortom motpolerna i det binära systemet. I dessa fall är det svårt att avgöra ifall termerna ses som könsidentiteter i sig eller som en mer allmän position utanför tvåkönsnormen och/eller cisnormen. Det samma gäller för en informants svar som är intressant ur både textuell och ideationell synvinkel, nämligen "hen". Detta nya könsneutrala pronomen har i diskursen kommit att indexera könsidentiteter utanför det normativa, och uppenbarligen kan det också fungera som ett sätt att verbalisera den egna könsidentiteten.

Ordet queer utnyttjas också för kategorisering utanför cisnormen: några informanter använder termerna queer och genderqueer utan tillägg, medan det även förekommer svar av typen "Genderqueer man", "Queer, man" och "Queer tjej”. I enkäten ombads informanterna kort besvara frågan "Vad innebär ordet queer för dig?" och ett ständigt återkommande tema är just identiteter, beteenden och åsikter som i något avseende bryter mot tvåköns- och cisnormen (liksom även mot heteronormen). Tillägget (gender)queer kan då sannolikt omfatta allt från kritik mot traditionella könsroller till en egen identitet som ligger utanför cisnormen på en eller flera punkter. Ordet queer förekommer i någon variant i 11 av svaren, medan förleden trans- används av lika många informanter. I flera svar står ordet queer också ensamt. Genom användningen av queer vill informanterna sannolikt kategorisera sig utanför det normativa över lag, och uppvisar då vissa likheter med svaren "inget”, inget alls", ”(...) inget kön", "inget (non-gender)" och "Agender (könlös"). Sammanlagt 37 informanter identifierar sig inte med något kön alls, eller uppger "inget" som tillägg till andra samtidiga eller skiftande kön.

68 av personerna som besvarade enkäten uppgav förutom sin nuvarande könsidentitet också en eller flera tidigare identiteter. I några fall var svaret på bägge frågorna samma, vilket eventuellt beror på att informanten inte lagt märke till att frågan inte var obligatorisk. I de svar där en skillnad i beskrivningarna finns kan många olika typer av förändringar i identiteten urskiljas: från man till kvinna och tvärtom, från man eller kvinna till icke-binära identiteter eller till ingen specifik könsidentitet, från en icke-binär identitet till en annan och så vidare. Också skiftningar från icke-binära identiteter till man eller kvinna förekommer. Juridiskt kön efterfrågades också, och det juridiska könet stämmer exakt överens med könsidentiteten (man/man eller kvinna/kvinna) i 89 fall, vilket innebär att mer än hälften av informanterna har en identitet som inte fullständigt stämmer överens med myndigheternas kategorisering. Ibland är skillnaden liten (kvinna/"tant", man/"man, antar jag") men ibland, till exempel då en person juridiskt sett är kvinna men själv kategoriserar sig som man, kan diskrepansen ha märkbara konsekvenser för personens vardag, också i språkligt avseende. I Finlands namnlag ingår till exempel fortfarande bestämmelser om mans- och kvinnonamn, vilket försvårar namnbyten i vissa fall. 


\section{Självidentifiering i fråga om sexuell identitet}

Enkätfrågan om sexuell identitet var konstruerad så att informanterna antingen kunde kryssa i något av alternativen homosexuell, heterosexuell eller bisexuell eller formulera ett eget svar. Omkring hälften valde att kryssa i en ruta medan resten - 97 personer - föredrog att beskriva sin identitet med egna ord, och jag kommer här främst att koncentrera mig på de senare. På den textuella nivån kan konstateras att en stor majoritet av svaren består av ett enda ord. De 34 beskrivningar som är längre än så består av liknande listor som i fallet kön, eller av en till tre meningar.

39 informanter kategoriserar sig som homosexuella och 13 som heterosexuella, utan preciseringar eller alternativa formuleringar. Gemensamt för dessa kategorier på det semantiska planet är att de positionerar såväl personen själv som hens potentiella partners som tillhörande en viss könskategori, även om vilken denna kategori är sedan varierar. I diskursen om homo- och heterosexualitet tenderar begreppen att knytas till en binär syn på kön, något som ändå inte nödvändigtvis alltid är fallet - en person med androgyn könsidentitet kan till exempel kategorisera sig som homosexuell ifall hen endast känner dragning till andra androgyna.

I fråga om bisexualitet positioneras inte personen själv utan endast potentiella partners, som då kan vara antingen män eller kvinnor. Förleden $b i$ - har givetvis en koppling till tvåkönsnormen etymologiskt sett men behöver inte nödvändigtvis innebära att personen i fråga inte är intresserad av personer med icke-binära könsidentiteter. Genom användningen av pansexuell inkluderas också icke-binära identiteter, och i många sammanhang verkar pansexuell och bisexuell vara mer eller mindra synonyma. Då det egna könet inte inkluderas i beskrivningen men partnerns kön har betydelse kan svaren se ut som följande: "queer, androsexuell", "gynekofil (attraherad av kvinnor)"och "flexibel, men föredrar kvinnor". Då själva könet inte spelar någon roll kan ändå egenskaper som traditionellt förknippas med kön vara relevanta: "kallar mig homo men struntar i kön, dras till feminina/androgyna personer". Sammanlagt 22 personer beskriver sig som pansexuella, med eller utan tillägg. "Pansexuell. Bisexuell. Eller helt enkelt bara sexuell", skriver en informant, och här blir kategorierna synonyma. En annan svarskategori som ligger nära den pansexuella i bemärkelse att könen inte ligger i fokus är den där personligheten betonas, som i svaren "tänder på personer" och "personligheter".

Förekomsten och omfattningen av sexuellt intresse för andra personer ligger också som grund för en del kategoriseringar. Fem av informanterna beskriver sig som asexuella, med eller utan kompletteringar, och sex personer beskriver sig som sexuella. Här ligger alltså fokus inte på kön, utan på avsaknaden respektive förekomsten av sexuellt begär. En informant beskriver sig också som demisexuell, en identitet som ligger nära asexualitet men där personen kan känna sexuell dragning till en person hen känner en särskilt stark känslomässig koppling till. Svaret, "Demisexuell biemotionell", tyder på att dessa personer i just det här fallet kan vara såväl män som kvinnor (och eventuellt även icke-binära). Känslomässiga, icke-sexuella aspekter betonas också i några andra svar: "Homoemotionell-bisexuell", "panromantisk" och "Svårdefinierat, pansexuell, 'själsligt' homosexuell och till viss del asexuell...". I terminologin kring sexualitet görs ofta åtskillnad på efterleden sexuell och romantisk, där fokus i det förra ligger på sexuell attraktion och sexuella handlingar och i det senare på emotionell attraktion, i praktiken ofta kärlek. En asexuell person kan alltså ha 
romantiska partners medan en person som känner sexuellt begär inte nödvändigtvis alls upplever emotionell dragning till andra människor, och undviker romantiska förhållanden.

Även andra aspekter på sexualiteten nämns. Svaret "Heterosexuell BDSM-utövare” är intressant eftersom fokus ligger, förutom på kön, på vilken typ av sexuella handlingar informanten är intresserad av - BDSM kan, som tidigare nämnts, placeras inom queerkategorin. I ett svar ligger sedan fokus även på mängden samtidiga relationer. Beskrivningen "'omni'sexuell, polyamorisk (poly-bi i vardagstal)" syftar på flera samtidiga förhållanden där partnerns kön kan vara vilket som helst.

Termen queer är rätt vanligt förekommande också i fråga om sexualitet, i och med att den ingår i 42 av svaren. Även här är det svårt att avgöra vad som i praktiken avses då informanten beskriver sin sexualitet som queer eller använder queer som bestämningsord. I vissa fall preciseras det ändå: "Queer, eftersom jag tänder på fler än två kön" och "Queer (oavsett kön)" pekar på en identitet som ligger nära eller är identisk med pansexualitet. I svaret "Min sexuella läggning är homosexuell, min sexuella identitet ryms kanske inte riktigt i det begreppet. Den är liksom mer - queer." görs skillnad på sexuell läggning och sexuell identitet, men vilken skillnaden är preciseras inte. En informant uppger endast att hen har en "queer syn på sexualitet", utan hänvisning till den egna identiteten.

Identiteter som är föränderliga och fall där informanten är osäker på sin identitet förekommer även här, och osäkerhetsmarkörer som används är kanske, liksom och skulle kunna beskriva. Mestadels, oftast och ibland tyder i sin tur på en föränderlig identitet. "Vet inte. Homosexuell, kanske bi.", uppger en informant, medan en annan skriver "kanske homo? queer? blandat.". En föränderlig identitet uttrycks i svaret "Flytande, men oftast hetero". Flera personer vill eller kan inte alls kategorisera sig i fråga om sexualitet: "Odefinierat", "Ingenting" och "Osäker" är exempel på den här typen av svar. Även i fråga om sexualitet skiftar alltså i vissa fall fokus från identiteten till själva kategoriseringsprocessen.

\section{Slutsatser}

Självkategoriseringen i fråga om kön och sexualitet tyder inte bara på att det finns en uppsjö olika identiteter, utan svaren kan också bidra med en del insikter i hur identiteter kan verbaliseras samt hur identitetskategorierna i fråga och till dem relaterade normsystem uppfattas.

Samtliga informanter identifierade sig som queera i fråga om kön och/eller sexualitet. I sina definitioner av termen queer nämner de icke-normenliga identiteter, handlingar och uppfattningar, ofta med fokus på heteronormen, cisnormen och tvåkönsnormen. Många självkategoriseringar baserar sig sedan på i vilka avseenden identiteten inte är normenlig: i fråga om kön betonas det icke-binära och det föränderliga, i fråga om sexualitet betonas parternas kön på ett sätt som positionerar informanten utanför heteronormen. Särskilt i svaren gällande kön väljer också de personer som har en mer normenlig identitet att precisera, diskutera, markera föränderlighet och uppge alternativ. En betydande del av informanterna kan eller vill dessutom inte alls kategorisera sig i fråga om kön, eller använder endast termen queer. De kan då positionera sig utanför kontinuumet manligt-kvinnligt (som till exempel termen androgyn refererar till), eller så kan de uppleva kategorisering överhuvudtaget som irrelevant eller omöjligt. Många uppgav också samtidiga eller skiftande/situationsbundna identiteter, och 
många hade upplevt en eller flera förändringar i sin könsidentitet. Juridiskt kön och könsidentitet stämmer fullständigt överens hos mindre än hälften av informanterna.

I fråga om sexualitet betonas förutom personens eget och potentiella partners kön också andra faktorer. En av dessa är i vilket omfång personen alls är sexuellt attraherad av andra, eller om intresset snarare ligger på ett emotionellt, romantiskt plan. Några informanter uppgav sig helt enkelt vara sexuella, utan precisering. Också tvåsamhetsnormen tangerades i en beskrivning, och i en annan normerna för sex i sig då BDSM-sex nämndes. Även i fråga om sexualitet ville en del informanter inte överhuvudtaget kategorisera sig, eller så användes den synnerligen breda termen queer.

Definitionerna har ofta normen som referenspunkt, också då det handlar om icke-normenliga identiteter. Många svar kan innehållsmässigt karakteriseras som beskrivningar av vad som inte ingår i identiteten, snarare än precisa beskrivningar av personens identitet. Här vill jag återkomma till tanken om genderism, det vill säga de ojämlika maktstrukturer som går att urskilja i fråga om kön - vissa kategorier är kraftigt normaliserade och en positionering utanför normen innebär en positionering som icke-man, icke-heterosexuell, icke-cisperson och så vidare, snarare än en beskrivning av vad personen i fråga är. Svaret "queer", som är vanligt förekommande $\mathrm{i}$ fråga om både kön och sexualitet, är ett exempel på just detta: queer är kanske inte i sig ett kön eller en sexualitet, utan snarare ett förhållningssätt till dessa eller en enormt bred identitetsposition utanför det normativa. Något som framstår som klart är att många av de aspekter på kön och sexualitet som framkommer i svaren sällan synliggörs i språkvetenskaplig forskning. Enkätsvaren antyder att kategorin kön är ett sammelsurium av kroppsliga, utseendemässiga, beteendemässiga och psykologiska aspekter, medan kategorin sexualitet inte bara omfattar olika parters kön utan även många andra faktorer som förhållanden, handlingar och emotioner. Rörlighet, samtidighet, situationsbundenhet, osäkerhet och även något som vid traditionell kategorisering skulle uppfattas som motstridighet gick att uppfatta i många beskrivningar.

Fokus i den här undersökningen ligger på det queera men det betyder inte att normenliga identiteter är mindre mångfacetterade eller intressanta ur språkvetenskaplig synvinkel tvärtom kan just brott mot normen hjälpa oss förstå även det normenliga, något bland annat Cameron och Kulick (2003) skrivit om. "Man", "kvinna" och "heterosexuell" är även de identiteter som konstrueras diskursivt, precis som "icke-binär transperson" och "homoemotionell-bisexuell". Queera identiteter ska alltså inte bara inkluderas i språkvetenskapen, utan de kan ge oss värdefull kunskap om hur sociala kategorier konstrueras, upprätthålls och förändras. Olika typer av undersökningar och ingrepp i språket kräver sedan fokus på olika aspekter av kön och sexualitet. När är kategorisering överhuvudtaget relevant, när är det juridiskt kön vi avser då vi talar om kön, och hur könar vi kroppar, beteende och utseende? Hur kan emotioner, förhållanden och handlingar inkluderas i termen sexualitet, och vilka normer relaterade till dessa finns? Här framgår det tydligt att klassisk kategorisering med skarp gränsdragning fungerar illa $\mathrm{i}$ fråga om kön och sexualitet, medan mer kognitivt baserade modeller som Roschs prototypteori kunde utgöra en mer hållbar semantisk grund.

En mångfacetterad syn på kön och sexualitet gör utan tvekan språkvetenskapen mer komplicerad och försvårar kvantitativa undersökningar, men en snäv syn där bara vissa identiteter inkluderas kan leda till snedvridna forskningsresultat samtidigt som den försvårar jämställdhetsarbetet i och med osynliggörandet av marginaliserade individer och grupper. Forsknings- 
insatser som Wojahns (2015) avhandling om feministisk språkaktivism och Hornscheidts (2015) trans_x_ing-projekt, liksom flera publikationer om pronomenet hen, tyder på att en intersektionell queerfeministisk språkvetenskap håller på att etableras som ett alternativ till mer essentialistiskt förankrad forskning om språk och identiteter.

\section{Referenser}

Ambjörnsson, Fanny. 2006. Vad är queer? Stockholm: Natur och kultur.

Barrett, Rusty. 2002. Is queer theory important for sociolinguistic theory? I: CampbellKibler, Podesva, Roberts \& Wong (red.): Language and Sexuality: Contesting Meaning in Theory and Practice. Stanford, CA: CSLI Publications. S. 25-43.

Bing, Janet M., \& Bergvall, Victoria L. (1996). The question of questions: Beyond binary thinking. I: Coates (red.): Language and gender: A Reader. New York : Longman. S. 495-510.

Cameron, D, \& Kulick, J. 2003. Language and Sexuality. Cambridge, Cambridge University Press.

Eckert, Penelope. 2002. Demystifying Sexuality and Desire. I: Campbell-Kibler m.fl. (red.): Language and Sexuality: Contesting Meaning in Theory and Practice. Stanford: CSLI Publications. S. 99-110.

Fox, Melodie J. 2011. Prototype theory: An alternative concept theory for categorizing sex and gender? I: Smiraglia (red.). Proceedings from North American Symposium on Knowledge Organization, Vol. 3. Toronto, Kanada. S. 151-159.

Hornscheidt, Lann. 2015. Trans_x_ing linguistic actions and linguistics. I: Magnusson m.fl. (red.): Könskonstruktioner och språkförändringar: Rapport från den åttonde konferensen om språk och kön. Stockholm: Södertörns högskola. S. 29-46.

Visser, Irene. 1996. The prototypicality of gender. Contemporary notions of masculine and feminine. I: Women's Studies International Forum, vol. 19, nr 6. S. 589-600.

Wojahn, Daniel. 2015. Språkaktivism: Diskussioner om feministiska språkförändringar $i$ Sverige från 1960-talet till 2015. Skrifter utgivna av Institutionen för nordiska språk 92. Uppsala: Uppsala universitet.

Zimman, L., Davis, J. \& Raclaw, J. (red.). 2014. Queer Excursions: Retheorizing Binaries in Language, Gender and Sexuality. New York: Oxford University Press.

Finlex. 1985. Namnlag. 〈http://www.finlex.fi/sv/laki/ajantasa/1985/19850694> [Tillgänglig 4 april 2016].

Riksförbundet för homosexuellas, bisexuellas, transpersoners och queeras rättigheter. 2016. Begreppsordlista. <http://www.rfsl.se/hbtq-fakta/hbtq/begreppsordlista/> [Tillgänglig 4 april 2016].

Regnbågsankan. 2016. Fakta. <http://www.regnbagsankan.fi/utbildning-skolbesok/fakta-omhbtiq/> [Tillgänglig 4 april 2016]. 